\title{
Pengaruh Jus Buah Jambu Biji Merah (Psidium guajava L) terhadap Gambaran Histopatologik Trakea Mencit (Mus Musculus) Strain Swiss yang Dipaparkan Asap Rokok
}

\author{
Novi Febrianti , Rita Yuli Suryati \\ Progam Studi Pendidikan Biologi, Universitas Ahmad Dahlan \\ Kampus III, Jl. Prof. Dr. Soepomo, SH, Yogyakarta, 55164 Indonesia \\ surat elektronik: novifebrianti@pbio.uad.ac.id
}

\begin{abstract}
ABSTRAK
Jambu biji merah adalah salah satu buah-buahan yang mengandung antioksidan tinggi. Penelitian ini bertujuan untuk mengetahui pengaruh jus buah jambu biji merah terhadap gambaran histopatologik trakea mencit yang dipaparkan asap rokok dan dosis yang paling efektif untuk mengurangi dan mencegah efek yang ditimbulkan oleh paparan asap rokok

Penelitian ini menggunakan 3 perlakuan dosis jus buah jambu biji merah yaitu 0,I3 ml/mencit/hari (PI), 0,26 ml/mencit/hari (P2) dan 0,52 ml/mencit/hari (P3) dengan 3 macam kelompok kontrol yaitu kontrol tanpa perlakuan $(\mathrm{K})$, kontrol negatif yang hanya dipaparkan asap rokok $\left(\mathrm{K}^{-}\right)$dan kontrol positif menggunakan dosis vitamin $\mathrm{C} 0,02 \mathrm{ml} /$ mencit/hari $\left(\mathrm{K}^{+}\right)$. Tiap perlakuan menggunakan 3 ekor mencit. Parameter yang diamati adalah gambaran mikrokopis jaringan epitel trakea. Data hasil penelitian dianalisis secara deskriptif dengan membandingkan jaringan epitel trakea antar kelompok perlakuan.

Hasil penelitian menunjukkan bahwa jus buah jambu biji merah berpengaruh terhadap jaringan epitel trakea mencit yang dipaparkan asap rokok. Pemberian jus buah jambu biji merah dapat mengurangi kerusakan epitel trakea mencit akibat paparan asap rokok. Dosis jus buah jambu biji yang efektif untuk mengurangi kerusakan trakea adalah $0,26 \mathrm{ml} /$ mencit/hari atau setara dengan mengkonsumsi 100 gr buah jambu biji bagi manusia setiap hari.
\end{abstract}

Kata kunci: buah jambu biji merah (Psidium guajava), mencit (Mus musculus), trakea, asap rokok

\section{Pendahuluan}

Indonesia adalah negara tropis yang kaya akan berbagai jenis buah-buahan. Salah satu jenis buah yang banyak dijumpai adalah jambu biji merah. Buah ini harganya relatif murah sehingga banyak dikonsumsi masyarakat. Selain harganya yang murah, buah ini juga mengandung antioksidan yang tinggi sehingga bermanfaat bagi kesehatan tubuh.

Menurut O'Dell (1999) dalam Wiralis (2009), jambu biji merah mengandung senyawa fitonutrien sebagai antioksidan diantaranya vitamin $\mathrm{E}$, vitamin $\mathrm{C}$, selenium, zinc, asam elagik, lignin antocyanidin dan fenol flavonoid. Kandungan antioksidan yang variatif ini merupakan potensi yang besar untuk dapat menangkap radikal bebas, terutama radikal bebas dari asap rokok.

Rokok adalah salah satu barang yang sering dikonsumsi masyarakat Indonesia. Jumlah perokok setiap tahunnya mengalami peningkatan, termasuk dari kalangan pelajar. Merokok terbukti dapat menyebabkan berbagai gangguan kesehatan. Bahaya yang disebabkan oleh asap rokok tersebut ternyata bukan hanya dapat diderita oleh perokoknya sendiri, tetapi bahaya terbesar akan diderita oleh orang yang berada di sekitarnya dan terkena paparan asap rokok tersebut (second hand smoker). Radikal bebas yang terdapat dalam asap rokok merupakan penyebab utama berbagai penyakit.

Sistem pernafasan merupakan sistem organ yang paling rentan terkena dampak negatif paparan asap rokok. Widayati (2013) meneliti adanya erosi pada sel epitel mukosa bronkiolus dan penebalan pada septum interalveolaris pada mencit yang dipaparkan asap rokok. Penelitian ini bertujuan untuk mengetahui pengaruh pemberian jus buah jambu biji merah terhadap gambaran histopatologik trakea mencit yang dipaparkan asap rokok dan dosis yang paling efektif untuk mengurangi kerusakan akibat paparan asap rokok.

\section{Metode Penelitian}

Penelitian ini merupakan penelitian eksperimental laboratorik Penelitian dibagi dalam tiga tahap, yaitu 
determinasi tanaman jambu biji merah, pengujian pemaparan asap rokok dan pemberian jus buah jambu biji merah, serta pembuatan preparat trakea mencit.

Determinasi tanaman dilakukan di laboratorium Sistematik Tumbuhan Universitas Gadjah Mada (UGM).. Pemaparan asap rokok dan pemberian jus buah jambu biji merah, dilakukan di Laboratorium Penelitian dan Pengujian Terpadu (LPPT) UGM, Pembuatan preparat dilaksanakan di laboratorium Patologi Fakultas Kedokteran Hewan UGM.

Tahap pengujian dalam penelitian ini dibagi dalam 6 kelompok perlakuan yang terdiri dari K: kelompok kontrol (tanpa perlakuan); K-: kelompok kontrol negatif (dipaparkan asap rokok dan tidak diberi jus buah jambu biji); K+: kelompok kontrol positif (dipaparkan rokok dan diberi Vitamin C); PI: kelompok yang dipaparkan asap rokok dan diberi jus buah jambu biji dosis 0,13 ml/mencit/hari; P2: kelompok yang dipaparkan asap rokok dan diberi jus buah jambu biji dosis $0,26 \mathrm{ml} /$ mencit/hari; P3:

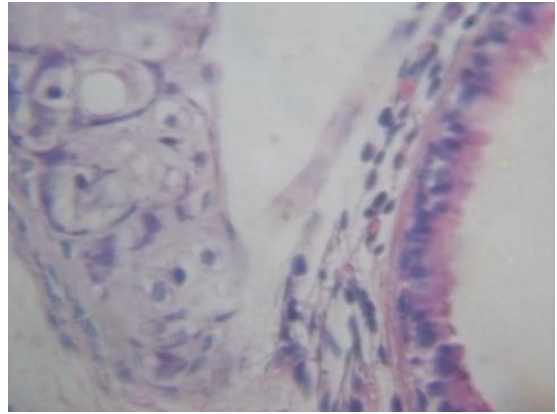

K

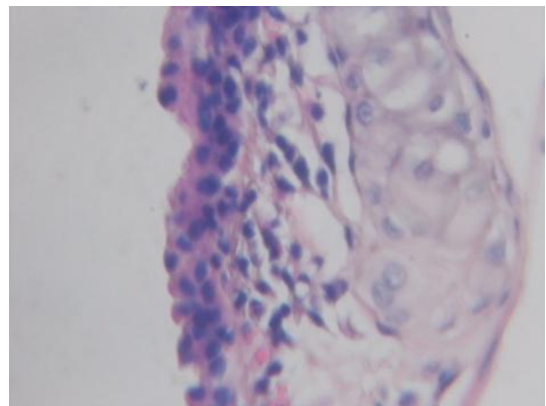

K-

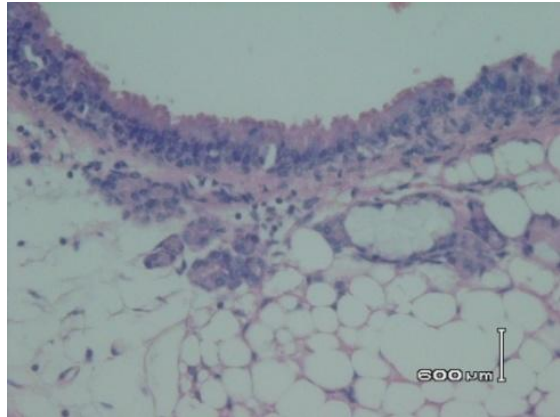

$\mathrm{K}+$ kelompok yang dipaparkan asap rokok dan diberi jus buah jambu biji dosis $0,52 \mathrm{ml} /$ mencit/hari. Parameter yang diamati adalah jaringan epitel trakea meliputi silia dan sel epitel.

\section{Hasil dan Pembahasan}

\section{Determinasi tanaman jambu biji merah}

Determinasi dan identifikasi tanaman jambu biji dilakukan untuk memastikan bahwa tumbuhan yang dipakai dalam penelitian ini adalah tanaman jambu biji. Berdasarkan hasil determinasi, dapat diperoleh kepastian bahwa tanaman yang digunakan dalam penelitian ini merupakan tanaman jambu biji.

\section{Gambaran Histopatologik Trakea Mencit}

Pemaparan asap rokok menimbulkan kerusakan struktur trakea mencit. Gambaran kerusakan tersebut dan pengaruh pemberian jus buah jambu biji merah dapat dilihat pada Gambar I.

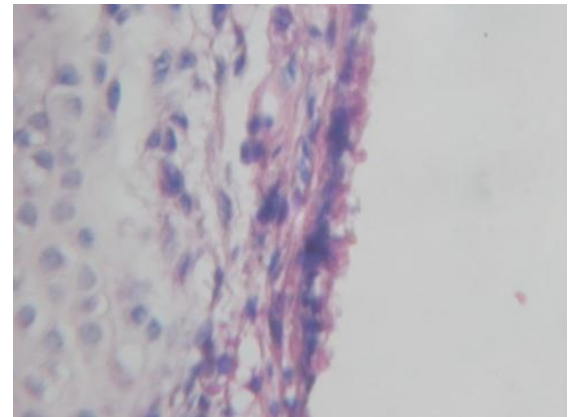

PI
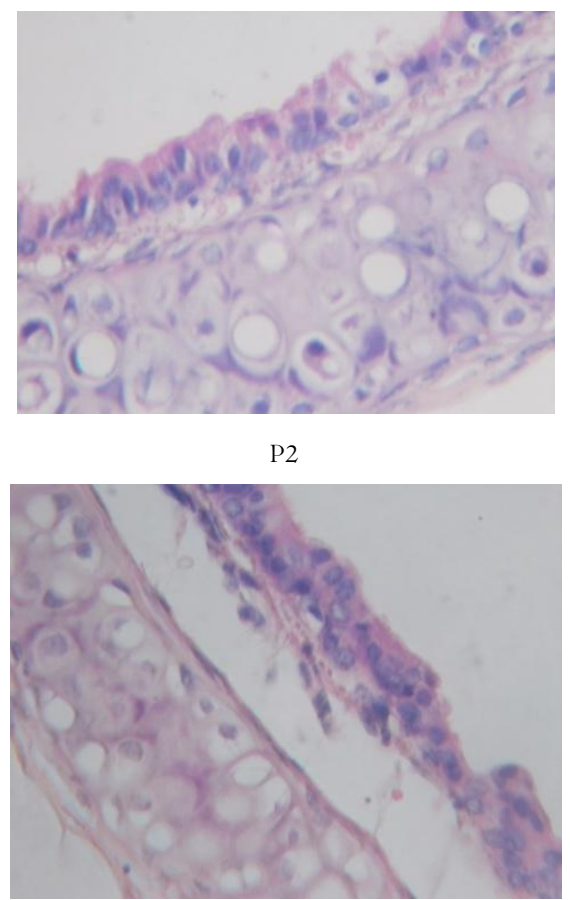

P3

Gambar I. Gambaran histopatologik trakea mencit yang dipapar asap rokok dan diberi jus buah jambu biji merah pada perbagai dosis Keterangan : (K (kontrol tanpa perlakuan; K- (hanya dipapar asap rokok); $\mathrm{K}+$ (dipapar asap rokok dan diberi vitamin C 0,156 ml/mencit/hari); PI (dipapar asap rokok dan diberi jus buah jambu biji $0,13 \mathrm{ml} /$ mencit/hari; P2: ( dipaparkan asap rokok dan diberi jus buah jambu biji dosis $0,26 \mathrm{ml} / \mathrm{mencit} /$ hari; P3: ( dipaparkan asap rokok dan diberi jus buah jambu biji dosis $0,52 \mathrm{ml} / \mathrm{mencit} /$ hari. 
Pengamatan dilakukan pada jaringan epitel trakea mencit yang dipaparkan asap rokok. Paparan asap rokok terbukti dapat merusak jaringan epitel trakea. Jaringan epitel adalah jaringan yang membentuk lapisan yang menutupi permukaan tubuh dan melapisi rongga-rongga tubuh.

Berdasarkan Gambar I, terlihat pada kelompok K sel epitel trakea tampak normal, sedangkan pada kelompok $\mathrm{K}$ - terlihat adanya atrofi sel epitel mukosa dan hilangnya silia dari sel epite.

Terjadinya atrofi sel pada sel epitel trakea mencit yang dipapar asap rokok merupakan suatu respon adaptasi. Atrofi sel ditandai dengan berkurangnya ukuran suatu organ atau sel karena mengecilnya ukuran sel dan atau berkurangnya jumlah sel. Jaringan atau sel yang mengalami atrofi disebut dalam keadaan atrofik. Atrofi tidak hanya berhentinya pertumbuhan tetapi juga pengurangan yang aktif dari ukuran sel dan atau jumlah sel yang diperantarai oleh apoptosis (Underwood,1999: 99).

Pada kelompok perlakuan $\mathrm{K}+$, susunan sel trakea mencit tampak normal, lapisan mukosa trakea tidak mengalami perubahan yang signifikan. Hal ini menunjukkan bahwa vitamin $\mathrm{C}$ dapat mencegah kerusakan jaringan epitel trakea. Hal ini karena vitamin C merupakan salah satu antioksidan sintetik.

Pada kelompok perlakuan PI(dosisi 0,I3 $\mathrm{ml} /$ mencit/hari), sel epitel lapisan mukosa trakea mengalami atrofi dan terdapat adanya erosi pada silia dan sebagian besar sel epitel. Pemberian jus buah sebanyak $0.13 \mathrm{ml} /$ mencit/hari belum mampu menunjukkan efek yang berarti atas kerusakan yang ditimbulkan asap rokok.

Selain terjadi atrofi, juga terlihat erosi silia dan erosi sel epitel trakea. Hal ini dapat disebabkan oleh adanya iritasi pada lapisan mukosa trakea yang tersusun atas sel epitel. Menurut Krisnabudhi, (2004), iritasi pada lapisan mukosa trakea akan menyebabkan erosi sel epitel lapisan mukosa trakea

Pada kelompok P2 (dosis $0,26 \mathrm{ml} /$ mencit/hari menunjukkan jaringan epitel trakea tidak mengalami perubahan yang signifikan, epitel tampak normal dan masih terdapat silia pada epitel. Dosis ini mampu mengurangi kerusakan jaringan epitel trakea mencit.

Pada kelompok P3 (dosis $0,52 \mathrm{ml} /$ mencit/hari) masih terlihat adanya atrofi dan erosi sebagian sel epitel mukosa trakea mencit. Diperkirakan dosis 0,52 $\mathrm{ml} /$ mencit/hari terlalu tinggi sehingga menimbulkan efek negatif terhadap struktur trakea mencit.

Atrofi dan erosi pada sel epitel trakea mencit yang dipapar asap rokok disebabkan karena adanya radikal bebas yang terdapat dalam asap rokok. Pemberian jus buah jambu biji merah pada berbagai variasi dosis dapat mengurangi kerusakan trakea akibat paparan asap rokok. Widayati (2013) yang meneliti pengaruh jus buah pepaya terhadap pulmo mendapatkan bahwa pemberian jus buah pepaya pada mencit yang dipaparkan asap rokok menyebabkan struktur pulmo kembali normal. Penelitian Mariyanti (2013) mendapatkan bahwa jus tomat juga mempunyai efek positif untuk mencegah kerusakan pulmo yang dipaparkan asap rokok karena aktivitas antioksidannya yang tinggi.

Kandungan vitamin $\mathrm{C}$ pada buah jambu biji merah merupakan salah satu antioksidan alami. Antioksidan berperan penting dalam proses perlindungan tubuh dari radikal bebas yang dapat timbul dari proses metabolisme tubuh maupun dari lingkungan luar seperti asap rokok dan asap kendaraan yang dihirup sehingga masuk ke dalam tubuh (Kumalaningsih, 2007).

\section{Simpulan}

I. Jus buah jambu biji merah dapat mempengaruhi gambaran histopatologik trakea mencit yang dipaparkan asap rokok dengan mengurangi kerusakan epitel trakea mencit akibat paparan asap rokok.

2.Dosis jus buah jambu biji yang optimal untuk mengurangi kerusakan trakea adalah 0,26 $\mathrm{gr} /$ mencit/hari atau setara dengan mengkonsumsi IO0 gr buah jambu biji bagi manusia setiap hari.

\section{Daftar Pustaka}

Arkeman, H, David. "Efek Vitamin C Dan E Terhadap Sel Goblet Saluran Nafas Pada Tikus Akibat Pajanan Asap Rokok". Universa Medicina. Vol.25 No.2

Harjana, Tri. 20I I. Buku ajar Histologi. Yogyakarta: UNY Press.

Kumalaningsih, Sri. 2007. Antioksidan Alami. Surabaya: Trubus Agrisarana.

Krisnabudhi. 2004. "Perawatan mandiri pasca trakeostomi”. Cermin Dunia Kedokteran. No 144

Underwood. 1999. General And Systematic Pathology, diterjemahkan oleh Sarjadi. Jakarta: EGC

Widodo, E. 2006. "Pajanan Asap Rokok Kretek Pada Tikus Putih Sebagai Model Untuk Manusia”. Thesis. Bogor: Institut Pertanian Bogor.

Wiralis. 2009. "Pengaruh Pemberian Jus Jambu Biji (Psidium guajava L) Terhadap Kadar Ion Nitrit Dan Gambaran Histopatologik Panus Sendi Adjuvant Induced Arthritis Tikus Wistar". Media Medika Indonesiana. Vol 43. No 4 .

Widayati, 2013, Pengaruh Carica papaya L terhadap Gambaran Histopatologik Pulmo Mencit (Mus musculus) yang Dipaparkan Asap rokok, skripsi, UAD, Yogyakarta. 